\title{
A Way Forward: The Future of Irish and European Union Financial Regulation
}

\author{
Rishi Ahuja ${ }^{a}$, Sean Barrett $^{a}$, Shaen Corbet $^{b}$, Charles Larkin $^{a, c *}$ \\ ${ }^{a}$ Trinity Business School, Trinity College Dublin, Dublin 2, Ireland \\ ${ }^{b}$ DCU Business School, Dublin City University, Dublin 9, Ireland \\ ${ }^{c}$ Institute for Policy Research, University of Bath, UK \\ *Corresponding Author:larkincj@tcd.ie
}

\begin{abstract}
The Irish financial crisis through the period between 2008 and 2012 caused unprecedented damage to the national economy while generating substantial inequality and demographic issues through the austerity measures that followed. While large amounts of taxation has gone towards understanding the events leading up to the crisis, there has not been a concentrated effort to consolidate the lessons learned within the Irish context. This paper seeks to fill that gap, providing an overview of the key lessons learned from the Irish experience of the European financial crisis. First, we interrogate the domestic response and evaluate the immediate government intervention and longer-term investigation process through the national Banking Inquiry commissioned by the Irish government. Second, we focus on the broader domestic policy lessons learned from the crisis. Lastly, we briefly evaluate some of key changes in European policy that will in turn shape the future of Irish regulatory policy. We find several areas where further reform is necessary, helping chart a path forward for future legislation in the financial regulatory space.
\end{abstract}

Keywords: Financial Crisis; Ireland; Financial Regulation; Banking Inquiry; Government Response.

\section{Introduction}

The scope, depth, and gravity of the Irish financial crisis between 2008 and 2012 have been well documented (Connor et al. [2012]; Corbet and Twomey [2014]; Corbet [2016]; Whelan [2014]). We now know that the total cost of bank recapitalisation has been an estimated $€ 64$ billion. Public debt held by the state jumped from $25 \%$ of GDP in 2006 to $107 \%$ at the end ${ }^{1}$ of 2011 . Since 2000 the Irish economy had witnessed steady, consistent growth, with GDP in current prices almost

\footnotetext{
${ }^{1}$ Department of Finance Monthly Economic Bulletin, January 2012.
} 
doubling up until the financial crisis. The main contributor to the total cost of the financial crisis is the lost GDP growth over the course of the period. Let us assume for a rough estimate that Irish GDP stayed constant at the high level in 2007. This would indicate that the total cost in lost GDP would be approximately $€ 153$ billion. Taking a more modest approach and holding GDP at the 2006 level would result in an estimated loss of $€ 49$ billion.

Through generated by a range of both domestic and international actors, a fairly comprehensive list of the events that lead up to the financial crisis both globally and in Ireland has been generated (Honohan [2009]; Kinsella [2012]; Lane [2011]). While there are still important facts that were established in public hearings carried out by the Banking Inquiry. The following research seeks to address the crucial residual question: what are the concrete policies and practices that can be implemented at both the domestic and international level to prevent such a crisis from occurring again in the future?

To address this question, we will cover three major areas of policy-making that we believe can strengthen both Ireland and the European Union's position on financial regulatory policy. First, we interrogate the domestic response to the financial crisis and the subsequent Banking Inquiry process. We find that there are several improvements that can be implemented to better assess threats in our financial system, respond when they occur, and subsequently investigate any wrongdoing. First, the Irish government should work in tandem with the Central Bank Commission to develop a more organised approach to interacting with financial institutions and a better system for recording decision-making. Second, a focused approach to the guarantee that did not include subordinate debt would have been less costly to the Irish taxpayers. Any future guarantees by the Irish government to address financial instability must be more targeted to minimise the eventual cost of the plan. Third, government assistance should have been tied to the removal of senior bank leadership and boards of directors that unequivocally failed at their duties, to the detriment of the state. Fourth, the Irish government should have mandated that financial institutions write-off a portion of nonperforming loans (NPLs) that are still hamstringing the recovery process. Additionally, there are several lessons learned from the Banking Inquiry process that should inform future policy responses including alterations to the timing, scope, and structure of future fact-finding efforts.

Secondly, we analyse the broader spectrum of financial regulatory law and policy. We find that there are still several critical opportunities to strengthen our financial system. Regulatory rules and procedures must be concrete and enforced consistently with more active supervision by the Oireachtas. Such regulatory processes must be anchored in data analysis as opposed to merely relying on the opinions of either the financial institutions being supervised or the regulatory authorities. Stress testing needs to be more robust across both the Central Bank processes and within the financial institutions themselves. The broader policy of moral suasion failed, and a higher level of scrutiny and data-driven analysis needs to be the new norm for Irish financial regulatory supervision. 
Finally, we look to Europe as a whole and offer suggestions regarding positive improvements that can be undertaken to strengthen the financial system across the region. Specifically, we recommend that the European Central Bank (ECB) provide direct liquidity to financial institutions to protect senior bondholders in EU as opposed to through domestic governments. The degree to which Irish taxpayers were liable for providing broader security across the EU as a whole was entirely inequitable. Risk sharing must be diffused across the sector, and the new Banking Union will hopefully assist in accomplishing that. In this section, we also raise the crucial issue of the Financial Trilemma as it applies to Ireland and provide commentary on the issues that arise through this challenge (Benediktsdottir et al. [2011]; Conefrey and FitzGerald [2010]; O'Sullivan and Kennedy [2010]; Kluth and Lynggaard [2013]). Further, we address key concerns surrounding whether the Banking Union, without a fully functioning fiscal backstop, will be able to adequately address the needs of the EU moving forward.

While the Banking Inquiry and other efforts have painstakingly worked to accurately understand the events leading up to the financial crisis, we must now assess the potential policy solutions that can be brought about to strengthen our economic system and to provide broader opportunity across the country. This paper intends to be a starting point for that discussion, outlining several key changes that can strengthen the state of domestic and EU financial regulatory structures.

\section{Analysing the Irish response to the banking crisis}

It is important to briefly outline the structure of the Joint Oireachtas Inquiry in the Banking Crisis (the Banking Inquiry). The IMF followed a framework of analysis throughout the European crisis that linked sovereigns-corporate-banks together in a nexus of transmission mechanisms that gave rise to vicious cycle effects pulling down countries and their financial systems. Figure 1 illustrates this framework:

\section{Insert Figure 1 about here}

Informing the Inquiry's outline is the idea that the political economy of Ireland at the close of the housing bubble was fundamentally attached to facilitating an economy based upon property. The Banking Inquiry aspired to discover the reasons why the Celtic Tiger failed so dramatically and how the banking-property-state nexus resulted in the Guarantee, the Bailout and the protracted period of high unemployment, low growth and fiscal austerity we have experienced over the past few years.

The less generous understanding of the Banking Inquiry is that it is a calculated programme of political theatre. There is a strong desire to find and punish the person or persons responsible. This is understandable. While academics and technocrats enjoy bettering their intellectual and official 
opponents rarely does their continued employment depend upon such successes. Furthermore, there exists a problem, in which members of the inquiry and witnesses had to be extremely careful about who is named in the course of hearings due to ongoing and potential legal implications. The push to drive things to a human scale creates the possibility of human responses. Recriminations and accusations are easily offered as analysis. Here say evidence is accepted as truth. Certain histories, born of memories of crisis meetings in the small hours of the morning, are given profound credulity by an audience that has come to expect a certain story. The story of evidence is the story of how law evolved from custom and practice to legal science. Parliaments have been the losers in this evolution for the most part. Parliament's powers to draw evidence towards itself and ensure its veracity has been thrown in high relief in this process. If the judiciary fears a parliament and a parliament fears a judiciary and both can ensure that the transaction cost for the slightest infraction will ensure the most deep-seated risk aversion dominates all public and private interactions by persons will there be such a thing as evidence or merely carefully crafted artifices that comply with the rules of engagement. The whole concept of scrutiny and oversight falls apart under such conditions. Parliament becomes theatre and policy becomes a product of artifice and not analysis.

Politics makes the process of analysis difficult since the Baconian norms that academics take for granted do not apply. Politics is different. The members are always conscious of the return on investment for every minute they listen to a senior civil servant or banker they are away from their constituency office or progressing a citizen's grievance against some aspect of officialdom. Political points scored against opposing parties or figures of public opprobrium can result in needed media coverage to remind people of their representative and that they are doing something they vaguely agree with (or more importantly, do not disagree with). The risk is that such events devolve into partisan circuses, creating much heat but little light. Due to very strict rules outlined in legislation such problems have been largely eliminated. At the same time alternative problems can be generated, where everyone is far too polite. This has already been an accusation against the Irish inquiry that participants are allowed to enter a public confessional, a national truth and reconciliation commission that imparts no blame following a televised mea culpa. As the picture of what happened from 1992 to 2008 in Ireland becomes clearer the immediate changes introduced between 2009 and now close many stable doors. The horses may have departed or been corralled back into their stalls but 'future-proofing' the financial system has been left to one side while these investigations take place. It is a concern that parliamentary investigations only discourage bold policy-making, finding solace in studying Thermopylae while awaiting the Somme, the past may be known and safe but it is the risky and uncertain known and unknown present and future that policymakers must engage. Some of these can be considered to be a function of policy cyclicality, something that the Bank of England is acutely aware of as it tries to telescope the decades and centuries to learn more about preventing policy failures. This was something that was not entirely present in the US Dodd-Frank Act (2010) that addressed the past and added complexity. While 
the sophistry of some legal and financial engineering may escape most of the population, the broad strokes of policy solutions are clearly understood by those who are willing to be moderately informed about the business of government. This has generated political responses which are important to note and address. The parliamentary process has not yet created enough change in culture, power distribution or equitable remedy. At present our esteemed colleagues of the legal profession have forged new and interesting approaches to the crisis. These startle economists and terrify financiers, such as the newly proposed German Abwicklungsmechanismusgesetz to implement the Single Resolution Mechanism. The response has been different forms of populism in different contexts (Corbet and Larkin [2018]).

In terms of providing scrutiny and oversight, the result is sub-optimal. A political and policy environment is created in which a cacophony of views eventually coalesce around demagoguery, and more worrying well-intentioned demagoguery, while politics somewhat descended into a quagmire of personal advantage versus public benefit the state of the banking systems of Europe continues to cause concern. While micro and marcoprudential regulations have been put in place, Ireland's banking system is still very fragile. The Banking Inquiry thereby attempted to attribute responsibility. There are two schools of thought on such investigations. Some feel that they should be conducted while the crisis is still fresh, like the US Congressional investigation in 2009/10. Others would feel that more time should exist between the event and the analysis. The Pecora Commission highlights the benefit of this approach, in that his review of the actions that resulted in the Wall Street 1929 crash and subsequent rash of bank failures was much more powerful than earlier investigations $^{2}$. It is because of this distance that the 1933 Banking Act was much more stringent than the earlier version of Glass-Steagall. If we wait until the battlefield has been entirely cleared, do we get to a stage where people have moved on and see this as a waste of public money? What are the implications of discussing events which are essentially ongoing? Seven years is a long time but the events of the Guarantee are still raw and the obsession from the public and media betrays a lingering trauma, as if the shock of what happened to the nation has just set in. The depth of the crisis in Ireland, much like that in many other smaller countries across the EU, appears to cast a much longer shadow than in the US, UK or core Eurozone countries.

The practical reality of what has happened to the Banking Inquiry is the the media via was never found. A report which no single member sees as fully fit for purpose. It has improved in part due to the efforts of many of colleagues working flat out but ultimately it is a deeply flawed document that places into doubt the abilities of the Oireachtas. A recent OECD study of our Oireachtas has

\footnotetext{
${ }^{2}$ The Pecora Investigation was an inquiry begun on March 4, 1932, by the United States Senate Committee on Banking and Currency to investigate the causes of the Wall Street Crash of 1929. The name refers to the fourth and final chief counsel for the investigation, Ferdinand Pecora. His exposure of abusive practices in the financial industry galvanised broad public support for stricter regulations. As a result, the U.S. Congress passed the Glass-Steagall Banking Act of 1933, the Securities Act of 1933, and the Securities Exchange Act of 1934.
} 
already highlighted that Ireland's parliament ranks last in budgetary oversight in the OECD, this Inquiry's final report will only add more evidence as to the inability of the Oireachtas to ensure accountability.

\section{Central Banking: Theory and Reality}

The exchange of letters between then ECB president Trichet and the late Minister for Finance Brian Lenihan made clear that Ireland was being forced into an official sector bailout. This was something that the director of the IMF programme in Ireland, Ajai Chopra, expressed was an outrageous over extension of authority by the ECB during an address he made to Oxford University in late 2014. The ECB legally exists above national parliaments and is not accountable to them or to the Council of Ministers. As such it would not directly cooperate with the Oireachtas Banking Inquiry, it would only address the European Parliament and largely on non-specifics. A compromise was found by which Trichet would attend a meeting of the Institute for International and European Affairs, give an address on the new governance structures of the Eurozone and respond to questions in a semi-structured fashion in a neutral venue in Dublin and while not under oath. This was constitutionally correct for the ECB and the European institutions. While that may be considered collateral damage to an economist or technocrat as part of the process of 'good government' or ensuring that central banking does not become a crude instrument of the political business cycle, it does not mean that the political system will not look to intervene. It is clear that the position of the national and supranational central bank, something which makes up a large part of the Banking Inquiry's questioning, is under examination (Abolafia [2004]; Auerbach [1985]; Grier [1987]; Woolley [1985]). The response has been a clear questioning of the role of the lender of last resort (Fischer [1999]). Who has the power to deploy it, who has the access to it and what countermeasures are meant to accompany it at point of request? The unfortunate conclusion so far has been that the Lombard Street understanding of the lender of last resort has an unusual complication - the ability to maintain a structure that is a lender of last resort relies upon it never being required.

The challenge is that while this is taking place, reviews, such as the Banking Inquiry have no input and national parliaments have limited scrutiny over the implementation of the new laws. That does not mean that the Financial Trilemma of Financial Stability, International Banking, and National Financial Policies has disappeared. It has migrated to a more pliable space, in the public discourse, within the organisations themselves and in the courts. The role of the German Constitutional Court in Karlsruhe has been considered of the utmost importance to the evolution of the economic constitution of Europe. The Irish case brought by Thomas Pringle (Thomas Pringle vs. Government of Ireland the Attorney General C-370/12) before the court was one of the rare instances where a European national, in this case a sitting member of parliament, questioned the speed and direction of travel of the undebated economic constitution of Europe. The outline of 
the economic constitution of the EU and the Eurozone by Advocate General Kokott was the first statement of the new framework constructed through the Brownian motion of crisis meetings in Brussels. Importantly, except for the high officials and the highest ministers of cabinet, all this had been presented as a fait accompli to parliaments of Europe.

Patience with crisis management and financial reform has worn thin as a result of this approach to policy-making over the past seven years. All the while cultures have not changed and the dangerous feedback loops that made a financial crisis into an economic and political disaster still remain largely in place. Though the principle objective was to split the banking systems from the sovereign that situation has proved almost impossible, especially in the case of small countries and in an environment where debates over 'secular stagnation' and 'debt super cycles' only work to highlight one profound problem - painfully slow economic growth (Rogoff [2016]). In all circumstances the promises made by past governments and the ability to repay debts will be compromised if growth does not improve.

Ultimately many things stood in the way of this inquiry. Primarily the legal hurdles. An initial hurdle was time between the events occuring and the inquiry beginning. The inquiries in the US and UK took place in 2009 and 2010, most other countries had reported by 2011. The Public Accounts Committee conducted an earlier exercise in 2012 but that did not progress to the questioning stage. The Oireachtas process itself was hamstrung by the rejection of the Thirtieth Amendment to the Constitution in 2011 by a vote of 53\% 'no'. The internal procedures were quickly given over to two objectives, one legal and the other institutional: first, a great deal of risk aversion with respect to the maintenance of the good names of witnesses and organisations arising from previous legal decisions.

Another substantial issue was a desire to make the report 'accessible' to all readers. The result was a situation which even the investigation team and secretariat found unsatisfactory. We were constrained at every juncture. The questions were not that which were hoped to be asked but the product of a process of legally-vetted investigation. When it came to the report, the situation was made worse. The timeline was obviously too short to draft something coherent, where a little over six weeks was offered. But it was made worse by several constraints imposed by the legal system and 'accessibility'. The original framework was agreed on the 29 of October 2015 with a review of the final report between the 14 and 19 November in hard-copy only, under supervision by appointment, without the ability to bring technology into the room. This timeline slipped by about three days and once it was clear that no member was willing to stand over the original report a new 'Finalisation Team' was formed and subsequently a new draft was to be produced from the original 700 page plus document between the space of the 24 November and the 3 December. Ultimately, coherently redrafting 700 pages in such a short time was an almost impossible task. The legal constraints were highly debilitating during the drafting. The rule was simple, if an article, report or item of data was not directly put to a witness appearing or non-appearing during the process, then that 
documentation would be deemed, in effect, inadmissible to the final report. Legal definitions drew upon Irish legal norms, which in finance would only be partially correct, since UK legal norms hold for most financial transactions in this part of the world.

As for statements of findings, committee members had to live in fear of defamation laws and court decisions going back to the time of Jock Haughey in the early 1970s. Wherever contradictory statements were made in testimony, one had to defer judgement, even if there was documentary evidence to the contrary. What mattered at all times was the testimony. The result was that the inquiry would have drawn together a series of findings that lack clarity and punch and do not add to our knowledge. Since the findings were so weak, it is unsurprising that the recommendations are equally uninspiring. Whereas the Americans and British had legislative proposals formed at the end

of the Irish process, it resulted in a recommendation of following up on a European Commission Green Paper. Even Irish jurists have identified the problem of parliamentary oversight brought about by legal constraints. In the judgement upheld, the Abbylara decision from April 2000, essentially shut-down that inquiry and has since acted as a brake on all further investigations. The judges stated the Oireachtas had 'no inherent power' to set up inquiries that would damage reputations or rule on facts. Such powers were not granted by the Constitution and were 'neither normal or necessarily exercised in other democratic states'.

\section{Lessons Learned within the Irish Banking Inquiry}

One of the surprising challenges to the entire Inquiry was the appearance in the middle of the process of a whistleblower on the investigation team. Since the disclosure was related to collection and analysis of evidence from the Central Bank and other sources it was of course very important that the process of dealing with the whistleblower be perfectly above board. The final report exonerated the Inquiry but highlighted several structural problems with the Inquiry process, including those related to it taking place within the Oireachtas as opposed to under the Tribunals of Inquiry Act. It was made clear in the final report that investigations found 'There was agreement amongst all those to whom I (Mr. Allen) spoke and it was evident from the papers which I read that the manner in which the Banking Inquiry had been established is thought to be far short of ideal. There have been, and there are, stresses and strains and dissatisfaction.' This entire process sapped energy from the Inquiry and since it related to evidence collection, was a matter of serious concern that was not duly addressed during the Inquiry. In the UK such an event during a UK parliamentary investigation would be grounds from restarting the process and redesigning the inquiry. In the context of the Banking Inquiry, timing was a major difficulty. Since the Inquiry was formed so late in the life the current government it created a timetabling problem, one which was highlighted by the expert panel even at the start of the process. It created a limit to the number of witnesses and how public hearings could be conducted. Infamously with hearings lasting until nearly Midnight 
on several occasions and meetings outside of the Dail term to meet deadlines. While there are some out there that will say that they learned nothing from the Inquiry, it fair however that the public hearings did serve a clear purpose, as did the supporting materials and statements from non-appearing witnesses. There are a number of issues that stand out:

1. The lack of accountability and transparency: Ministers were able to draft legislation in secret and much of the contingency planning for a solvency/liquidity crisis took place behind closed doors during a time before panic but only opened up to a wider audience for review when the crisis was fully upon us.

2. Institutional cultures were perverse: It was clear that the banking system had evolved due to an addiction to cheap credit and a property bubble and the business models of the banking system and the construction sectors were uni-dimensional and incapable of surviving a change in the assumed external or internal conditions. The Central Bank and Department of Finance had developed internal cultures that hampered discussion and resulted in habits that encouraged internal disputes and risk aversion on the part of staff. It was clear that inter-agency coordination was not optimal.

3. The importance of some people breaking the rules: Kevin Cardiff's submission caused a number of legal feathers to be ruffled due to its 422 page length but the Committee made it clear that the document needed to be admitted despite it exceeding the requested 10 page submission. Mr. Cardiff's statement and testimony has provided one of the clearest statements of what was happening in Irish economic policy between 2007 and 2011.

4. How little has changed: The closing off of the Inquiry to December 2013 resulted in many of the new EU banking union developments not being discussed but it was clear that between 2008 and 2013 very little by way of reform took place. What did happen was a function of making the 29 of September 2008 Guarantee decision or unwinding its consequences. Now, facing into a new general election the appetite for reform is much reduced and this is unfortunate since the Inquiry illustrated how much change to standard operating procedure was necessary.

5. The need to advance the capabilities of the Oireachtas: The misadventures of the Inquiry were brought about by a lack of flexibility wrought from legal decisions woven with intended and unintended consequences and the tyranny of low expectations. Oireachtas reform was much discussed but never seriously progressed since it suits the government of the day to keep its back-benchers and opposition disengaged in the processes of scrutiny, oversight and governance. At the very minimum an independent budget office, like that which exists in the US is needed to inform members and improve parliamentary oversight of executive proposals 
and decisions with financial implications. Unless the political system tries to take more ownership from the executive and the civil service public faith in the system will continue to erode and poor decisions will go unchallenged and uncorrected.

It is most important to analyse in detail the initial responses taken by government and the specific steps, whether resulting in a positive or negative result when managing the crisis.

\subsection{Decision-Making Structure and Record Keeping}

There were several structural elements of the decision-making process that hampered the quality and clarity of the immediate government response. First, when meetings took place between government officials and the heads of the financial institutions under threat [Anglo Irish Bank, Bank of Ireland (BOI), Allied Irish Bank (AIB) amongst other smaller institutions], there was no policy or procedure in place mandating which government actors must be a part of the decision-making process. Specific mandates regarding who needs to be around the table when such decisions are taking place should be created. At a minimum, the heads of the Central Bank Commission, the Department of Finance, and the then Taoiseach should be involved in negotiations that have such widespread impact such as the banking guarantee. Additionally, it is plausible that members of the Oireachtas should also have a role in oversight and decision making over crucial decisions that impact economic growth in the country. At a minimum, one member from the Dail Eireann and Seanad Eireann should also have authorisation to participate in negotiations and agreements of such economic magnitude and ideally would participate on the Domestic Standing Group (DSG) in similar crisis circumstances. Indeed, a crucial question of the Banking Inquiry was to determine the extent to which the Oireachtas was given the information and tools necessary to effectively oversee government policy-making. Increasing information sharing and involvement would enhance and facilitate better oversight functions. Though decision making with such large ramifications would ideally voted on by the whole Oireachtas, minimal participation as outlined above is necessary to promote democratic accountability.

Furthermore, there should be a broader set of policies and practices that specify the scope of decision-making that can be formalised by the DSG, the Central Bank Commission, and the Oireachtas. It is unclear which bodies ultimately do and should have decision-making authority over important policy decisions such as ordering the guarantee, the length and structure of such a guarantee, and eventually the decision to nationalise various financial institutions (O'sullivan and Kinsella [2011]; Lastra [2008]; Lastra [2008]). Looking at the time-line of events presented in the 'Report on the Crisis in the Domestic Banking Sector ${ }^{3}$,' various meetings were held between financial institutions and the Department of Finance, the then Taoiseach's Attorney General's office

\footnotetext{
${ }^{3}$ Report of the Joint Committee of Inquiry into the Banking Crisis. Available at: https://inquiries.oireachtas.ie/banking/volume-1-report/chapter-1/
} 
and various other stakeholders. To maximise the efficiency of information flows, a consistent set of stakeholders should have been present at every interaction with the financial institutions in order to present a united front in terms of the government's response to the unfolding crisis. When the crisis manifested itself, our system of government was structurally unprepared to deal with the pace of decision making in a coherent and consistent manner. This can only be changed through more direct and conscientious design of protocols and procedures for crisis management.

Another key issue is the lack of minutes and/or formal record keeping of the meetings leading up to the guarantee or other key decisions. There are no consistent written records or minutes detailing the opinions of various stakeholders or a formal analysis weighing the pros and cons of the guarantee and nationalisation decisions. This lack of information severely limits our ability to understand the rational of the decision-making and the factors considered in the process. Without such critical information, it is hard to assess any flaws in the rational or analysis conducted by the government. Nevertheless, it is clear that there was a fundamental misunderstanding of the scope and severity of the problems occurring in the financial system. According to Nyberg [2011], 'The possibility that they might experience catastrophic losses in asset values into the future does not appear to have been given serious consideration even from a contingency policy point of view'.

\subsection{Blanket Guarantee}

Concurrent with other academic and professional analyses of the crisis, we also contend that the blanket guarantee and inclusion of subordinate debt was overly broad. Granted, we acknowledge the supreme difficulty of decision-making while the crisis was unfolding. Based on two central papers documenting the response and management of the crisis (Honohan et al. [2010]), it is apparent that there was a clear misinterpretation of the ongoing crisis as an issue of liquidity as opposed to overall solvency. As discussed by Nyberg [2011], 'There appears to have been no fears and, at most, a modest discussion on possible underlying acute solvency problems. This is true of the banks themselves as well as of the authorities.' Thus, the decision to guarantee all debt stemmed from a fundamental misunderstanding of the crisis at hand. The specific underpinning of this lack of information will be further explored later in this analysis. A key and unique aspect of the Irish bailout was the decision to guarantee dated subordinate debt. In fact, the inclusion of such debt 'was not necessary in order to protect the immediate liquidity position.' The two primary arguments in support of inclusion centred on the idea that doing so would help banks open new bonds and enhance the simplicity of the intervention as a whole. The first point is open to debate, but Honohan et al. [2010] argues that such a guarantee puts undue stress on the sovereign, potentially impacting the domestic bond market and thus current sovereign bondholders. The second point, however, lacks any firm theoretical basis. The decision to draw the line between the liabilities that would be backed and those that would not was, according to Honohan et al. [2010], 'arbitrary.' The guarantee was also broader than other comparable actions taken by other sovereign governments. For example, 
the Northern Rock guarantee only extended to existing deposits. The expansive nature of the Irish guarantee was incredibly costly, though concrete estimates of covering subordinate debt are hard to isolate.

A topic that is insufficiently covered in the Banking Inquiry surrounding the crisis and government response are the deep moral hazard concerns embedded in the government's blanket guarantee. Moral hazard refers to 'the tendency of insurance protection to alter an individual's motive to prevent loss.' Government intervention in financial markets is a breeding ground for moral hazard in that financial institutions can undertake huge risks in pursuit of exorbitant profits without eventually being responsible if and when those risks fail (Allen et al. [2015]; Dam and Koetter [2012]; Hellmann et al. [2000]; Nier and Baumann [2006]). Blanket guarantees arguably exacerbate, rather than limit, potential moral hazard concerns. The guarantees mandated no explicit changes to bank leadership, decision-making structure, or any other aspects of the financial institution's processes or practices. Thus, government intervention and liquidity support were offered without much in return in order to guarantee a change of behaviour on the part of financial institutions. Furthermore, in contrast to widespread economic thought on managing financial crises, Irish authorities sought the protection and maintenance of all Irish financial institutions instead of those that were deemed systemically important. Generally speaking, systemically important financial institutions are defined as financial institutions whose 'size, complexity and systemic interconnectedness, would cause significant disruption to the wider financial system and economic activity.' Irish institutions failing to meet that criteria should have been liquidated as opposed to being propped up at the expense of Irish taxpayers. That being said, serious concerns existed in regards to the contagion ramifications if smaller institutions were to collapse. Despite these fears, a consistent and common sense approach to unwinding smaller banks in partnership with the EU could have limited the liability of Irish taxpayers to strictly what was necessary to sustain the Irish economy.

\subsection{Bank Leadership}

The crisis unequivocally demonstrated the lack of sound leadership on the part of Irish financial institutions as they undertook exorbitant amounts of risk. According to Nyberg [2011], 'Finally, the Commission considered that, by virtue of their position, it was already clear that decision-makers and leadership in the various institutions must carry a large part of the immediate blame for the crisis.' Furthermore, 'People in a position to make decisions are and must be ultimately responsible for them regardless of what advice or suggestions they have received. The higher and more influential their position, the greater their responsibility.' Yet, throughout the crisis and post-crisis intervention by the government, bank leaders were not consistently removed from their positions despite evidence of monumental mismanagement. Though they were ultimately the central decision-makers for the Irish financial institutions, and thus responsible for their mismanagement, the Banking Inquiry has declined to assign any responsibility to individuals in leadership positions throughout the financial 
system. The decision to not pursue any action against individuals directly responsible for the erosion of the financial sector does not align with the commentary provided above. When the guarantee was enacted, strict provisions should have at least mandated a change in leadership and boards of directors for institutions that clearly were incapable of sufficient self-governance. Furthermore, in addition to changes in leadership, there arguably should have been penalties enacted against senior bank leadership that deliberately ignored sound data and information regarding the instability of their institutions.

Moral hazard is also a side effect of not removing bank leadership after clear evidence of mismanagement (Chang [2000]; Corsetti et al. [2006]; Hellmann et al. [2000]; Nier and Baumann [2006]). Though senior leadership across the Irish financial sector failed to ensure that their institutions maintained solvency, they were rewarded with government assistance and full collaboration without any real penalty. Bank leaders were able to take excessive risks while not being forced to face the full downside of that risk, inflating the potential for moral hazard in the Irish financial markets (Allen et al. [2015]; Corbet [2016]). Though one could argue that senior leadership might have been kept in the dark in regards to subordinate risk-taking, bank leadership is ultimately responsible for developing adequate controls and oversight processes to ensure stability within each financial institution (Persson and Tabellini [1993]).

\subsection{Covering Non-Performing Loans}

As argued by Dirk Schoenmaker [2013], the Irish government should take a more active role in writing off existing non-performing loans (NPLs). One of the key drags on the Irish economy is the residual, over-hanging debt that is potentially limiting investment and new lending. According to Schoenmaker, 'up to 20 per cent of SMEs and 7.2 per cent of households face payment arrears.' Facing such debt and uncertainty, GDP growth is bound to move slowly. A more robust government program for debt forgiveness would be an important step to facilitating growth. There are, however, reasonable counterarguments to the proposal. Financial institutions have indicated that moral hazard also applies at the household or small business level and there is a concern that covering private debt would lead to increased instability and more NPLs. Taxpayer funds, though, have actively rescued the financial system despite widespread concern of moral hazard. Those same taxpayer funds should also support average citizens and business owners to ensure widespread growth from the bottom up. Ideally, write-offs of private debt would have been incorporated in Irish and EU policy-making as a condition for access to emergency liquidity and recapitalisation. Nevertheless, such policies could still be implemented to spur continued growth. The Banking Inquiry has been the central response by the Oireachtas to understand the events of the financial crisis and to gain insight on potential policy improvements to enact moving forward. There are several structural elements of the Banking Inquiry, however, that have limited the efficaciousness of the process. 


\subsection{Logistics: Timing and Scope}

Perhaps the single greatest flaw in the organisation and implementation of the banking inquiry has been the limitations of scope placed on the analysis. The terms of reference of the Banking Inquiry limit the questions and findings to 31 December, 2013, leaving several crucial questions unanswered. One of the most important residual questions emerging from the crisis is a full and robust understanding of what the Irish taxpayer's return on investment has been on the over $€ 60$ billion invested in the financial system. The Irish public deserves a comprehensive understanding of where those dollars went and how they were spent. By limiting the terms of reference, the Banking Inquiry was unable to acquire crucial information regarding how these funds have been allocated and the extent to which Irish small business owners are being relieved of the crippling effects of lingering debt. Additionally, the scope of reference has limited discussion on huge changes in EU regulatory structures that will have a direct effect on Ireland. The advent of the Banking Union will have a dramatic effect on system-wide regulation, and the structure of the Banking Inquiry has limited any and all discussion of this important development. Thus, limiting the scope of reference undercut the Banking Inquiry's ability to capitalise on providing a comprehensive perspective on the lingering effects of the financial crisis on the current economy.

Furthermore, organising the Banking Inquiry process so long after the decisions were carried out has lead to a substantial reduction in the effectiveness of this process. While the UK, Iceland, Netherlands, Norway, Finland, Sweden, and many other nations all completed exhaustive parliamentary inquiries into their respective financial regulatory responses, Ireland lagged behind in terms of carrying out similar analysis. While such a delay could have been beneficial in terms of expanding the scope and data available to the Banking Inquiry to facilitate greater understanding, limitations on the terms of reference discussed above have minimised any of those positive impacts. Looking forward, Banking Inquiry processes should proactively start gathering information immediately as the extent of a crisis becomes evident as opposed to retroactively trying to accumulate information long after crucial information has been lost.

\subsubsection{Independence}

Another key issue regarding the Banking Inquiry has been the connection of the proceedings to the current political administration and the lack of external and independent voices in the investigation process. When such a system-wide collapse occurs in the economy, truly independent voices need to be heard outside of the political process. An independent commission, similar to the Financial Crisis Inquiry Commission composed of subject matter experts formed in the United States, may have added value in addition to potential inclusion of parliament members. Furthermore, the political nature of the Banking Inquiry has left the matter subject to intense

partisanship. This has been further exacerbated by the incumbent government's decision to organise the Banking Inquiry with a majority of members from their respective political party. Lastly, the 
quality and structure of questions asked of witnesses throughout the Banking Inquiry process has been sub-optimal. Including subject-matter experts to help draft and conduct the Banking Inquiry questioning would have added tremendous value. A truly independent process may have resulted in a higher level of analysis and more thorough quality of evidence.

\subsubsection{Privacy and Protection}

While we fully respect the need to protect individual legal rights and to ensure that the inquiry does not simulate a court proceeding, statutes shielding individuals from being referenced or criticised in the final report take these principles too far. The Banking Inquiry, at its core, was supposed to give the Irish public a comprehensive understanding of the individuals and institutions responsible for the collapse of the domestic economy. The public has a right to know which actors and institutions were involved and how decisions were made that eventually had a devastating effect on their livelihood. This means that individual names of people involved in central government leadership and at the head of financial institutions should be included in the report. The full scope of transparency should have included Cabinet-level discussion regarding the technical design of the bailout and the decision to pass a blanket guarantee. Without such minutes, notes, and details, we cannot get a full picture of the events that transpired throughout the crisis and the Irish government's response. The 2013 Act authorising the Banking Inquiry was limited to an 'inquiry, record, and report inquiry' model. Such a model only allows findings of fact that are 'uncontested.' Uncontested facts are few and far between, policy-making is always contested and the Banking Inquiry is charged with the challenge of taking a variety of disagreements and illustrating the fairest depiction of facts that accurately captures the events leading up to and through the financial crisis. A constitutional change or a broader sweeping authorisation for parliamentary inquiry is required to have the strength to generate comprehensive findings.

Lastly, restrictions by the Central Bank Act severely hampered the ability of the BI to analyse and work with the vast amount of data and information they received. Of the 500,000 pages received by the secretariat, 17,000 pages were actually seen by the Banking Inquiry committee members, much of it redacted due to the restrictions put in place due to the Central Bank Act. Furthermore, the Central Bank Act shields the institution from freedom of information requests, protecting 'any of the supervisory directives within the meaning of the Central Bank Act 1942' from public scrutiny. While we respect the general need for discretion, confidentiality, and protection for Central Banks from political meddling, this complete lack of public accountability is unacceptable. Parliament should propose amendments to the Central Bank Act to mandate information sharing when a financial institution either needs emergency capitalisation or is nationalised. In such circumstances, any rights to privacy or autonomy must be weighed against the taxpayer's right and desire for information. In total, the public will see only $3 \%$ of the documents received, a completely unacceptable figure. 


\subsection{Broader Policies and Practices}

It is also important that we highlight the key policy areas that need critical attention emerging from the crisis. It is aspired to address residual issues that need to be tackled in order to ensure a more stable and prosperous economy. The crisis illustrated profound shortcomings in Ireland's capacity, structures, and strategies for engaging the financial system. It is important to improve such performance to ensure that taxpayers are never liable for the kind of damage witnessed since 2008.

\subsubsection{Principles-Based Regulation and Moral Suasion}

The financial crisis illustrated the tremendous folly of the government's regulatory approach of merely establishing principles and moral codes and hoping that the financial sector would adequately safeguard the nation's economy. At its core, the principles based regulatory approach was motivated by two key ideas: light regulation would facilitate a thriving banking sector and thus higher economic growth and that the incentives of the financial sector and the government were aligned. Both principles were immensely flawed.

Treatment of loan to value (LTV) ratios should also be explored in the context of transitioning to a more strict and clear set of policy rules. Throughout the years leading up to the financial crisis, there was ample evidence that LTV ratios were steadily increasing on bank balance sheets, with higher LTVs creating more risk in the economy due to the fact that the size of the loans were growing in relation to the underlying value of the asset (in this case mortgages) (Diamond and Rajan [2009]; Gorton [2009]; Green and Wachter [2005]). According to Honohan [2009],

\subsubsection{Data-Driven Practices}

The Banking Inquiry process and other investigations into the crises have made it dramatically clear that Irish financial regulatory bodies need to adopt a more data-driven and empirically grounded philosophy to micro and macro prudential regulation. Financial regulatory services consistently relied on financial institutions to carry out their own empirical analysis of data regarding the stability of their loan portfolios and quantification of risk (Bourke [1989]; Goodhart et al. [2004]). The Irish financial regulatory authorities need to instead develop internal processes, in partnership with leading economists at Irish and international academic institutions, to quantify risk with models that are tested and trusted in a transparent manner. Simply relying on internal

calculations by financial institutions is not enough - regulators need access to loan level data from the financial institutions to independently assess the stability of the system.

Improved stress testing is a key area where a more thorough empirical approach is both warranted and necessary. Stress tests are processes put in place to simulate various economic phenomena to see if a bank's portfolio can sustain downturns in the macro economy. Stress-testing processes by financial regulatory bodies suffered from two primary shortcomings. First, they overly relied on 
findings produced internally by financial institutions as opposed to rigorously exploring the data independently. Second, the analyses focused on the most likely scenarios to emerge during the time period analysed, when the goal of a stress test is the exact opposite. Indeed, the very motivation of a stress test is to understand what happens to a portfolio or position when an unlikely event occurs - widespread contraction or collapses in asset prices. Analysis conducted by financial institutions and regulatory bodies focused on 'likely outcomes' as opposed to low-probability events that ended up occurring. In statistical terms, the tail-events were ignored on the distribution, leading to a substantial misunderstanding of risk.

\subsubsection{Regulatory Capture}

Perhaps the clearest lesson from the analysis conducted after the crisis, and the Banking Inquiry process at large, is the need for a profound shift in the regulatory culture in Irish financial regulatory bodies. Complacency, miscommunication, and a general lack of desire to engage in robust policymaking seemed to plague the regulatory apparatus at every turn, and serious consideration needs to given in terms of strategies to alleviate this pervasive challenge. One potential explanation for the lack of regulatory action is that the Irish institutions in charge of overseeing the financial sector were 'captured' by private interests. Capture theories apply scrutiny to the regulatory bodies in charge of policy implementation and provide insight as to why regulatory bodies, and the Irish regulatory sector in particular, failed to substantially enforce financial regulatory policies. Capture arguments are primarily focused on the dynamics of regulatory application - seeking to understand the intricacies of the relationship between the regulator and regulated body. In the case of the financial sector, capture arguments could help shed light on the lack of regulatory movement as the financial system became over-leveraged and severely in need of government intervention.

\subsubsection{Regulatory Structure}

A key theme throughout the literature reviewing the financial crisis was the continued problems that arose due to the fragmented nature of the financial regulatory system. Confusion and dissension over the scope and jurisdiction of the Central Bank of Ireland (CB), the Irish Financial Services Regulatory Authority (FR), and the Department of Finance (DoF) led to substantial gaps in the regulatory policy structure, resulting in crucial shortcomings in terms of micro and macro prudential supervision of the financial sector. According to Nyberg [2011], 'One possible consequence of this 'silo think' was that the DoF, discouraged from interfering in the work of the independent FR and $\mathrm{CB}$, remained seriously underweight in professional financial expertise and engagement. The Commission considers it likely that the lack of overall analysis and responsibility in so many Irish public institutions may have allowed a number of warning signs to remain undetected.' It is important that penalties assessed during consumer protection functions are not subordinated due to the potential risk of destabilising a financial institution. Ensuring that both mandates are carried out effectively is a challenge that is perhaps exacerbated in a consolidated regulatory environment. 


\section{The European Union}

The policies of quantitative easing and the ECB's OMT have radically changed the behaviour of all financial markets and as a result the banking system with different implications for different countries depending on creditworthiness and trade patterns. This dramatic shift in monetary policy stance is presented in Figure 3 and 4, where we can observe the sharp decreases in interest rates and the implementation of multiple quantitative easing programmes. Ultimately the monetary policy operations resulted in credit allocation decisions being made by central banks and that these organisations have worked beyond the price stability mandate. The final area would be related to the socialisation of losses within the financial sector and sovereign distress. The design of the Guarantee resulted in the need for a Bailout, in combination with other external events connected to the Deauville Declaration in October 2010. Overall the temporary solutions to the design flaws of the original EMU have evolved over the past few years as a result of the sovereign debt crisis, quantitative easing, and the zero-interest-rate-policy (ZIRP). Long-run analyses of responses to debt, as have been done by Reinhart and Rogoff [2014] have begun to address some of the more likely long term scenarios, such as abrupt or slow defaults facilitated by stagnation or the role of financial repression as defined by Reinhart and Sbrancia [2015]. The Eurozone was an economic and monetary union that lacked a banking union. The Stability and Growth Pact continued only certain aspects of the convergence criteria, considering that others would be successfully addressed by the ESCB and ECB. In the absence of the exchange rate and the domestic interest rate, the behaviour of the Irish economy was allowed to change in ways that would not have been previously possible due to external pressures placed on the punt as the real effective exchange rate deteriorated. Ireland's desire to join the Eurozone was driven by the traditional impossible trinity of policies facing countries with pegged currencies as presented in Figure 5.

\section{Insert Figures 3, 4 and 5 about here}

In the absence of a banking union, where free capital flows were facilitated by the new currency system, Ireland needed to modify its policy approach to policy formation in the fiscal and monetary spaces. The gaps between the convergence criteria and entry into the Eurozone on 1 January 1999 were sizeable ${ }^{4}$. The criteria of an optimal currency area highlights the importance of consolidated fiscal policy across members of the currency zone and the importance of fiscal transfers, as well as labour mobility (Masson and Taylor [1993]; Lane [2006]). These facts were present but consider

\footnotetext{
${ }^{4}$ The reference criteria were: 1 ) Inflation no more than 1.5 percentage points above the average of the 3 countries with the lowest rates; 2) Long term interest rates no more than 2 percentage points above the average of the 3 countries with the lowest rates; 3) Exchange rate - within normal band of the Exchange Rate Mechanism for previous 2 years; 4) National budget deficit less than 3\% GDP; and 5) National debt less than $60 \%$ of GDP - or heading in the right direction
} 
of the utmost importance in the Irish context. The Irish approach to fiscal was coloured by the experience of the 1980s and the fiscal consolidation that took place as part of the protracted recession and Ireland's labour market was nearing full employment at the time. Schoenmaker [2012] has provided substantial evidence that the ECB placed unduly stringent demands on the Irish taxpayers by mandating complete coverage of the recapitalisation costs. The ECB's insistence on zero loss sharing by senior debt holders was a completely one-sided extortion of the Irish government and an inappropriate abuse of their structural role. The insistence of the EU on completely shifting liability to the Irish taxpayer has been akin to benefiting from the ensuing stability without accepting any of the costs to achieve such stability. Thus, the European Stability Mechanism should consider in the future, directly working with troubled banks as opposed to forcing sovereign government's into one sided policy arrangements (Nugent [2017]).

The other area under-appreciated but of concern is the rise of the shadow banking system. In a bank regulation version of Goodhart's Law, the aspects of the banking system that are regulated suddenly become ineffective for policy purposes and as seen with the bailout of AIG, the shadow banking system is developing rapidly and falls outside much of the regulatory changes since 2007, even those outlined in the European Commission banking union regulations and directives. In the interest of providing recommendations that in some way 'future proof' some of the findings of the Inquiry, it would be necessary that some thought be put into the analysis of the shadow banking system within Ireland and the Eurozone. The NY Federal Reserve has provided a basic outline of the shadow banking work. A map of the US shadow banking system is provided here to illustrate the importance of trying to incorporate this expanding aspect of the financial architecture in the US as presented in Figure 6.

\section{Insert Figure 6 about here}

In the context of the financial crisis, the EU has responded with the formation of the Banking Union. The Banking Union has sought to fully transition from national financial regulatory schemes to a broader EU approach, situating more regulatory authority in the hands of the ECB This broader authority focuses on a Single Rulebook for European banks mandating capital requirements, a deposit guarantee scheme, and a bank recovery and resolution process (Goyal et al. [2013]; Howarth and Quaglia [2013]; Schoenmaker [2012]). Under this new scheme, the ECB has been given supervisory authority and the responsibility for handling new EU wide regulatory oversight. The question of moral hazard at the EU level, though, is still a key concern (Gropp and Vesala [2004]). EU policy needs to be structured to minimise the potential cost of moral hazard and to ensure that financial institutions are adequately restricted from excessive risk and prohibitively penalised if such risks are taken. On net, we believe that Ireland will benefit from such changes in that consolidation of regulatory processes across the EU will allow small, open economies to ac- 
tively engage with the rest of the EU market with a more certain process to manage financial risk. Furthermore, such structures would fully internalise the externalities so dramatically demonstrated during the financial crisis. Irish taxpayers would no longer be fully responsible for the coverage of international senior-bond holders, and a wider EU safety net would be responsible for a broader share of the system's stability and financial health.

\section{Concluding Comments}

The financial crisis of 2008 brought unprecedented harm to the Irish economy, creating immense hardship and suffering in the country. Though many important policy improvements have been made, there are several key issues to explore moving forward to help strengthen the stability and effectiveness of our system. Though the Banking Inquiry has provided value through testimony that covers a breadth of events and actors that participated in the financial and regulatory sectors up to and through the crisis, the process is light on providing tangible steps for the country to take moving forward. This analysis has sought to compliment the Banking Inquiry by offering a set of concrete proposals to ensure a more stable and equitable Irish economy. We therefore offer a number of key policy recommendations that are established throughout our work.

Primarily, it is necessary to broaden participation and membership of the DSG and ensure more adequate democratic oversight and clear policies and practices mandating the government's approach to holistically responding to financial crises in terms of process management and robust group coordination. There must be substantial attention paid to the design of rules based around record-keeping to ensure adequate documentation of the evidence and decision-making process used to make key choices about the Irish economy, while limiting future guarantees and supports of the financial sector to specific assets critical to overall stability. Further, the inquiry processes should start closer to the events in question and be given broad time references to ensure full access to the information and data necessary to inform the public while independence should be codified in the Inquiry process where a commission of individuals outside of government should spearhead the investigation process.

There must also be an unequivocal end to principles based regulation and moral suasion where rules should be concrete, clear, and enforced to ensure an equitable and efficient financial sector while time-varying LTV ratios constrained at $90 \%$ should be the new normal to limit excessive risk taking. To improve information flows, financial regulatory bodies must seek loan level data from regulated financial institutions, derive independent models for stress testing and analysis, and conduct their own investigations of bank liquidity and stability while regulatory bodies must evaluate ways to promote a 'cultural shift' within their organisations to promote a more pragmatic perspective on the financial system. Within a European context the ECB must work directly with financial institution to provide liquidity where sovereign taxpayers cannot be fully liable for providing broader 
stability across the EU. More discussion and analysis are needed to understand and interpret key developments in EU regulatory policy that will impact the structure of domestic financial regulation. An initial assessment of recent efforts to strengthen and consolidate EU supervision has been positive while the EU will need a deposit insurance scheme and a more credible fiscal backstop. While remaining one of the most arduous and painful economic shocks in recent history, it is important that policy-makers and regulators take note of the significant shocks and distribution of responsibility that took place in Ireland after economic collapse. The above lessons could help to mitigate the severity of such shocks in the future.

\section{Declaration of Competing Interest}

The authors declare that they have no known competing financial interests or personal relationships that could have appeared to influence the work reported in this paper.

\section{Bibliography}

Abolafia, M. Y. (2004). Framing moves: interpretive politics at the federal reserve. Journal of Public Administration Research and Theory 14(3), 349-370.

Allen, F., E. Carletti, I. Goldstein, and A. Leonello (2015). Moral hazard and government guarantees in the banking industry. Journal of Financial Regulation 1(1), 30-50.

Auerbach, R. D. (1985). Politics and the federal reserve. Contemporary Economic Policy 3(5), $43-58$.

Benediktsdottir, S., J. Danielsson, and G. Zoega (2011). Lessons from a collapse of a financial system. Economic Policy 26(66), 183-235.

Bourke, P. (1989). Concentration and other determinants of bank profitability in europe, north america and australia. Journal of Banking \& Finance 13(1), 65-79.

Chang, H.-J. (2000). The hazard of moral hazard: untangling the asian crisis. World development 28(4), 775-788.

Conefrey, T. and J. FitzGerald (2010). Managing housing bubbles in regional economies under emu: Ireland and spain. National Institute Economic Review 211(1), 91-108.

Connor, G., T. Flavin, and B. O'Kelly (2012). The us and irish credit crises: Their distinctive differences and common features. Journal of International Money and Finance 31(1), 60-79. 
Corbet, S. (2016). Turning tigers into piigs: The role of leverage in the irish economic collapse. In Lessons from the Great Recession: At the Crossroads of Sustainability and Recovery, pp. 21-55. Emerald Group Publishing Limited.

Corbet, S. and C. Larkin (2018). Populism and extremism: The immediate political challenges to europeanism. Geoforum.

Corbet, S. and C. Twomey (2014). How have contracts for difference affected irish equity market volatility? The Economic and Social Review 45 (4, Winter), 559-577.

Corsetti, G., B. Guimaraes, and N. Roubini (2006). International lending of last resort and moral hazard: A model of imf's catalytic finance. Journal of Monetary Economics 53(3), 441-471.

Dam, L. and M. Koetter (2012). Bank bailouts and moral hazard: Evidence from germany. The Review of Financial Studies 25(8), 2343-2380.

Diamond, D. W. and R. G. Rajan (2009). The credit crisis: Conjectures about causes and remedies. American Economic Review 99(2), 606-10.

Fischer, S. (1999). On the need for an international lender of last resort. Journal of economic perspectives 13(4), 85-104.

Goodhart, C., B. Hofmann, and M. Segoviano (2004). Bank regulation and macroeconomic fluctuations. Oxford review of economic Policy 20(4), 591-615.

Gorton, G. (2009). The subprime panic. European Financial Management 15(1), 10-46.

Goyal, R., P. K. Brooks, M. Pradhan, M. T. Tressel, M. G. Dell'Ariccia, and C. Pazarbasioglu (2013). A banking union for the euro area. International Monetary Fund.

Green, R. K. and S. M. Wachter (2005). The american mortgage in historical and international context. Journal of Economic Perspectives 19(4), 93-114.

Grier, K. B. (1987). Presidential elections and federal reserve policy: An empirical test. Southern Economic Journal, 475-486.

Gropp, R. and J. Vesala (2004). Deposit insurance, moral hazard and market monitoring. Review of Finance 8(4), 571-602.

Hellmann, T. F., K. C. Murdock, and J. E. Stiglitz (2000). Liberalization, moral hazard in banking, and prudential regulation: Are capital requirements enough? American economic review 90(1), $147-165$.

Honohan, P. (2009). What went wrong in ireland. Prepared for the World Bank. 
Honohan, P., D. Donovan, P. Gorecki, and R. Mottiar (2010). The irish banking crisis: Regulatory and financial stability policy.

Howarth, D. and L. Quaglia (2013). Banking union as holy grail: rebuilding the single market in financial services, stabilizing europe's banks and'completing'economic and monetary union. Journal of Common Market Studies 51(S1), 103-123.

Kinsella, S. (2012). Is ireland really the role model for austerity? Cambridge Journal of Economics 36(1), 223-235.

Kluth, M. and K. Lynggaard (2013). Explaining policy responses to danish and irish banking failures during the financial crisis. West European Politics 36(4), 771-788.

Lane, P. R. (2006). The real effects of european monetary union. Journal of Economic Perspectives $20(4), 47-66$.

Lane, P. R. (2011). The irish crisis. The Euro Area and The Financial Crisis, 59.

Lastra, R. M. (2008). Northern rock, uk bank insolvency and cross-border bank insolvency. Journal of Banking Regulation 9(3), 165-186.

Masson, P. R. and M. P. Taylor (1993). Currency unions: a survey of the issues. Policy issues in the operation of currency unions, $3-51$.

Nier, E. and U. Baumann (2006). Market discipline, disclosure and moral hazard in banking. Journal of Financial Intermediation 15(3), 332-361.

Nugent, N. (2017). The government and politics of the European Union. Palgrave.

Nyberg, P. (2011). Misjudging risk: Causes of the systemic banking crisis in ireland. Report of the Commission of Investigation into the Banking Sector in Ireland.

O'Sullivan, K. P. and T. Kennedy (2010). What caused the irish banking crisis? Journal of Financial Regulation and Compliance 18(3), 224-242.

O'sullivan, K. P. V. and S. Kinsella (2011). An institutional architecture for meta-risk regulation in irish banking: Lessons from anglo irish bankâĂŹs minsky moment. Journal of Banking Regulation 12(4), 342-355.

Persson, T. and G. Tabellini (1993). Designing institutions for monetary stability. In CarnegieRochester Conference Series on Public Policy, Volume 39, pp. 53-84. Elsevier.

Reinhart, C. M. and K. S. Rogoff (2014). Recovery from financial crises: Evidence from 100 episodes. American Economic Review 104(5), 50-55. 
Reinhart, C. M. and M. B. Sbrancia (2015). The liquidation of government debt. Economic Policy 30(82), 291-333.

Rogoff, K. (2016). Debt supercycle, not secular stagnation. Progress and confusion: the state of macroeconomic policy, 19.

Schoenmaker, D. (2012). Banking supervision and resolution: the european dimension. Law and Financial Markets Review 6(1), 52-60.

Schoenmaker, D. (2013). Governance of international banking: The financial trilemma. Oxford University Press.

Whelan, K. (2014). Ireland's economic crisis: The good, the bad and the ugly. Journal of Macroeconomics 39, 424-440.

Woolley, J. T. (1985). Monetary politics: The Federal Reserve and the politics of monetary policy. Cambridge University Press. 


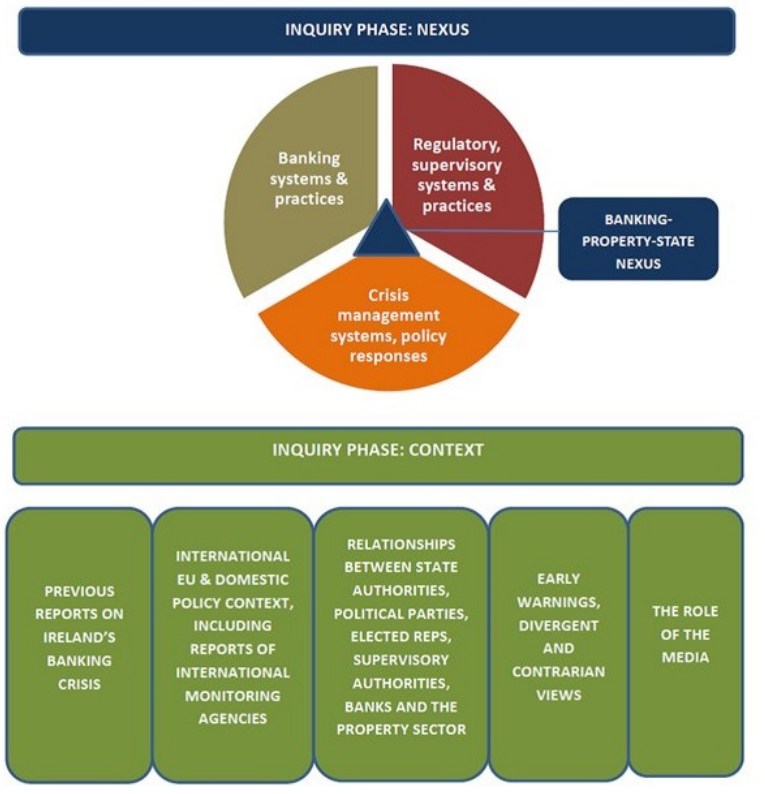

Figure 1: Joint Oireachtas Banking Inquiry Framework of Analysis Source: Joint Oireachtas Inquiry into the Banking Crisis. 


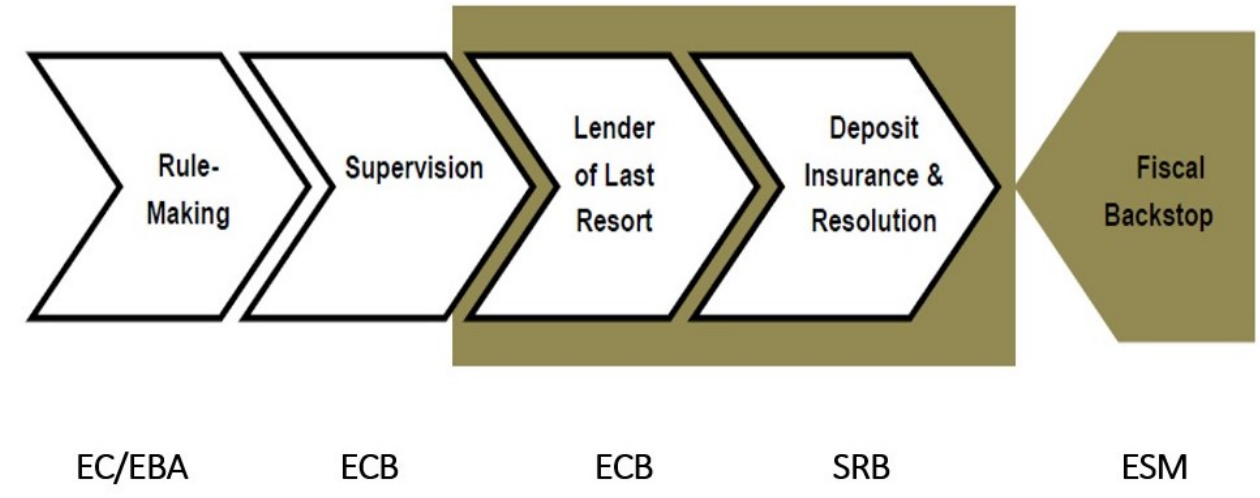

Figure 2: European System Structure

Source: Schenmaker, Dirk. 'The Financial Trilemma.' INFINITI Global Finance Conference, Prato 9 June 2014.

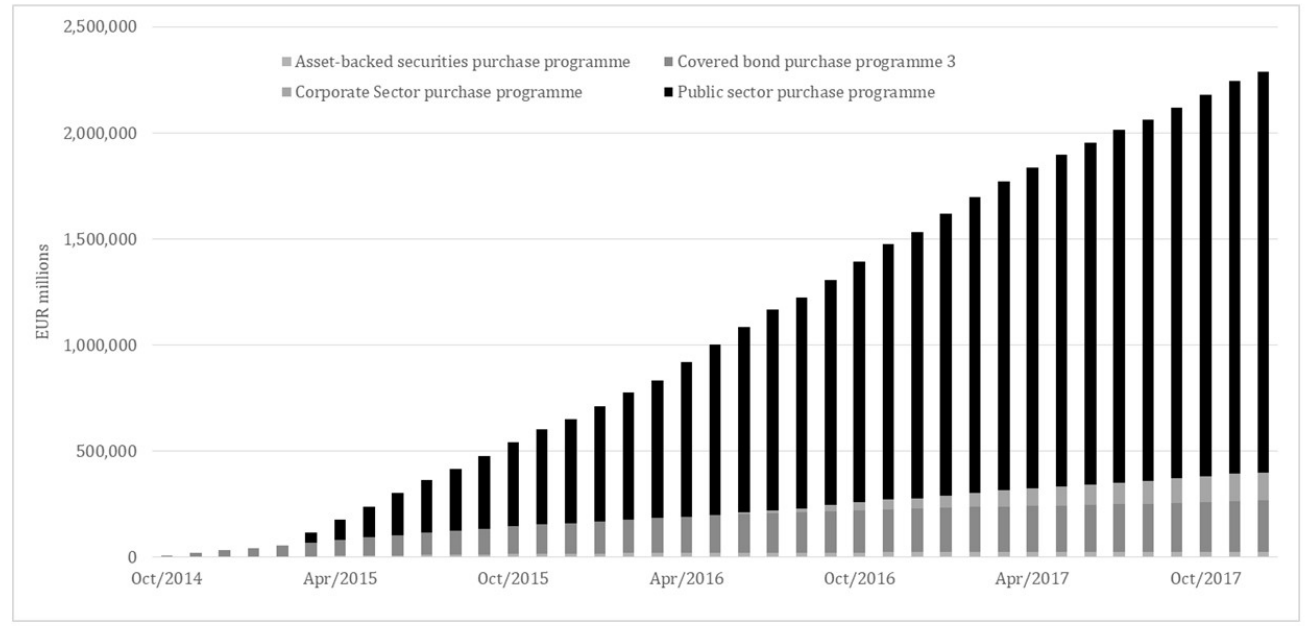

Figure 3: European Asset Purchase Programmes, Cumulative net purchases, 2014-2017 


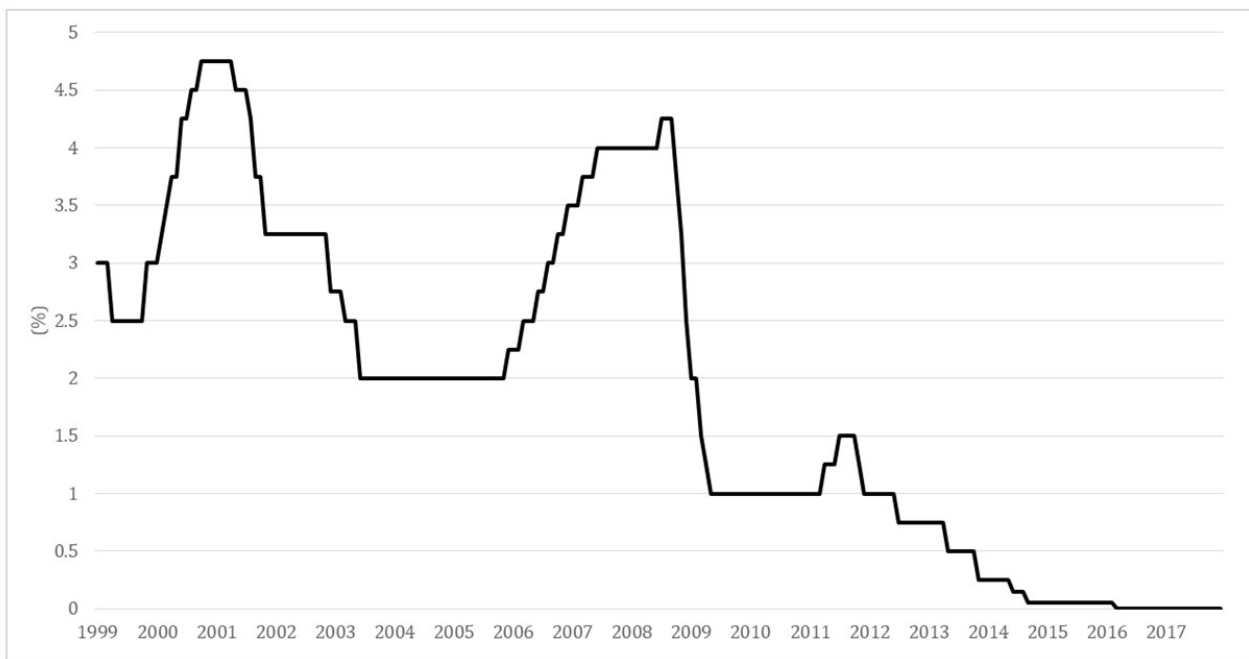

Figure 4: ECB Main Refinancing Rate 1999-2017

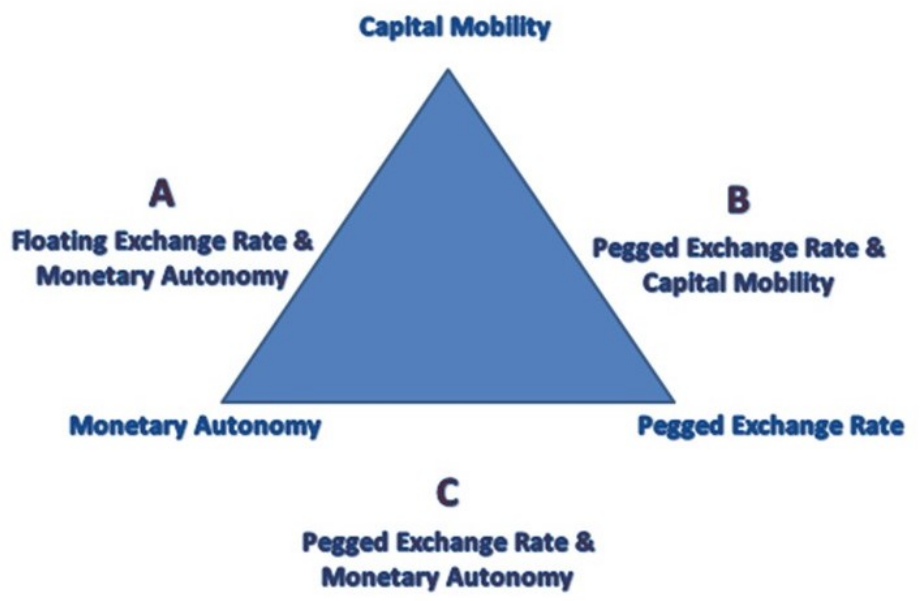

Figure 5: Classic Fixed Exchange Rate Impossible Trinity - Ireland 1979-1998. 


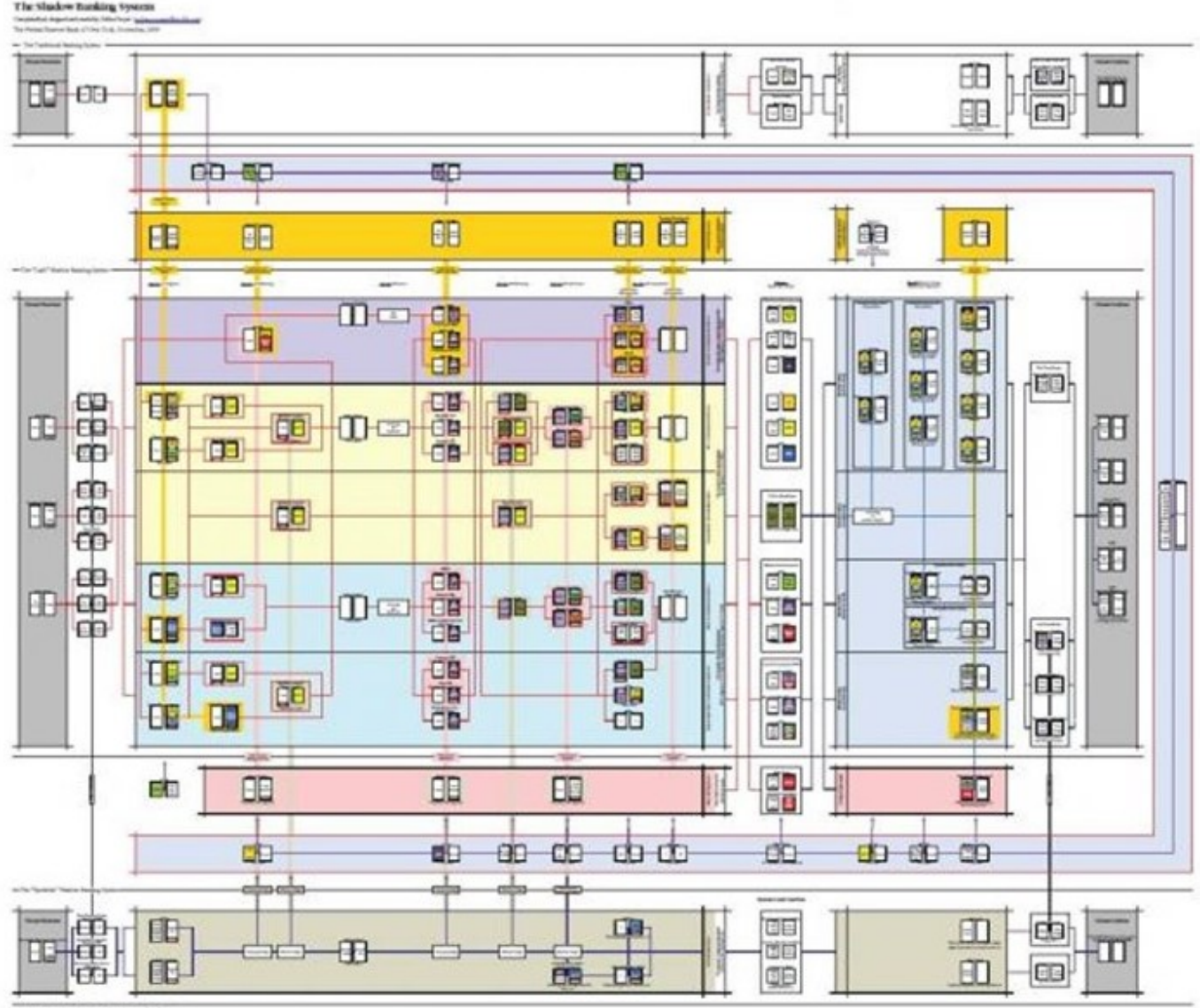

Figure 6: Map of the Shadow Banking System

Source: Zoltan Pozsar, Tobias Adrian, Adam Ashcraft, and Hayley Boesky. Shadow Banking. 2013. 